\title{
L-securinine inhibits the proliferation of A549 lung cancer cells and promotes DKK1 promoter methylation
}

\author{
SHUWEN HAN ${ }^{1}$, XI YANG $^{2,4}$, YUEFEN PAN ${ }^{1}$, QUAN QI ${ }^{1}$, JUNJUN SHEN ${ }^{1}$, HUIFEN FANG $^{1}$ and ZHAONING JI ${ }^{3}$ \\ ${ }^{1}$ Department of Medical Oncology, Huzhou Central Hospital, Huzhou, Zhejiang 313000; ${ }^{2}$ Department of Oncology, \\ Wannan Medical College, Wuhu, Anhui 241000; ${ }^{3}$ The Cancer Center, Yijishan Hospital \\ of Wannan Medical College, Wuhu, Anhui 241001, P.R. China
}

Received January 20, 2016; Accepted June 2, 2017

DOI: $10.3892 / 01.2017 .6693$

\begin{abstract}
L-securinine is a natural product extracted and isolated from the leaf of dried Securinega suffruticosa. The aim of the present study was to explore the effects of L-securinine on proliferation, and the methylation profile of the dickkopf-related protein 1 (DKK1) gene in human lung cancer cells and fibroblasts. L-securinine was extracted, isolated and the structure was identified. The cytotoxicity of L-securinine in A549 cells was evaluated by Cell Counting Kit- 8 assays. The expression and DNA methylation profile of DKK genes was analyzed by reverse transcription-quantitative polymerase chain reaction and bisulfite sequencing polymerase chain reaction, respectively. L-securinine inhibited the proliferation of lung cancer cells; the half-maximal inhibitory concentration values were $8.92,4.73$ and $3.81 \mu \mathrm{g} / \mathrm{ml}$, at 24,36 and $48 \mathrm{~h}$ post-treatment, respectively. DKK1, 2 and 3 expression was significantly increased in A549 cells compared with HLF-a cells. L-securinine induced the downregulation of DKK1 in A549 cells in a dose-dependent manner and induced methylation changes at $\mathrm{CpG}$ sites in the DKK1 promoter region. L-securinine may be a potential anticancer drug that mediates its effects by altering DKK1 gene methylation.
\end{abstract}

\section{Introduction}

Lung cancer remains the primary cause of cancer-associated mortality worldwide with a 5-year survival rate of $<15 \%$ (1), despite advances in diagnostic and therapeutic approaches. Significant advances have been made in understanding cancer

Correspondence to: Dr Zhaoning Ji, The Cancer Center, Yijishan Hospital of Wannan Medical College, 2 Zheshan West Road, Wuhu, Anhui 241001, P.R. China

E-mail:924441173@qq.com

Present address: ${ }^{4}$ Department of Interventional Radiotherapy, Huzhou Central Hospital, Huzhou, Zheijiang 313000, P.R. China

Key words: L-securinine, lung cancer, DKK1, methylation biology, including lung cancer, with the identification of oncogenic drivers of the disease (2).

In the present study, the cytotoxicity of L-securinine in human lung cancer A549 cells was evaluated. Securinines, including the two optical isomers L-securinine and D-securinine, are a class of natural products isolated from the plants of the Euphorbiaceae family. Securinine was extracted and isolated from Securinega suffruticosa (3) and structurally characterized in 1963 (4). Securinine has been applied as a treatment for blood $(5,6)$ and nervous system diseases (7-9). Previous publications have reported that L-securinine can induce cell apoptosis in human breast cancer MCF-7 cells (10) and human promyelocytic leukemia HL-60 cells (11).

The Wnt signaling pathway is involved in a wide range of developmental and physiological processes, including cell fate specification, tissue morphogenesis and homeostasis (12). The loss or gain of function of Wnt pathway components can result in the development of hepatocellular, lung or colon cancer (13). Certain factors of the Wnt signaling pathway have been considered as potential therapeutic targets for cancer treatment (14). Dickkopf-related proteins (DDKs) are Wnt signaling pathway inhibitors that are frequently inactivated in certain types of human cancer (12). In the present study, the expression of DKK genes in A549 cells treated by L-securinine was determined by reverse transcription-quantitative polymerase chain reaction (RT-qPCR).

Epigenetics is defined as the mechanism by which cells transfer environmental change-induced phenotypes to their daughter cells (15). Epigenetic changes are heritable changes in gene expression that do not alter the primary DNA sequence (16). Emerging evidence suggests that epigenetic changes, including genomic methylation, serve crucial regulatory roles in X-chromosome inactivation, mammalian development, gene silencing, retrotransposon silencing and genomic imprinting (17). Aberrant methylation profiles of genes are associated with cancer, in addition to autoimmune disease, psychiatric and neurodegenerative disorders, diabetes and heart disease (18). The addition of a methyl group to the carbon-5 position of the cytosine present in the $\mathrm{CpG}$ dinucleotides is a common methylation event of DNA in eukaryotes (19). These CpG dinucleotides act as either $\mathrm{CpG}$ islands or as dispersedly distributed $\mathrm{CpG}$ motifs within gene promoter regions. Multiple methods, including 
methylation-specific PCR, methylation-sensitive restriction enzyme PCR, pyrosequencing and bisulfite sequencing PCR (BSP), can be used to detect the CpG islands and motifs (20). Nevertheless, BSP is the gold standard for detecting DNA methylation (21). BSP was used to detect the DNA methylation profile of DKK1 genes in the present study.

\section{Materials and methods}

Extraction, isolation and structure identification of L-securinine. A total of $700 \mathrm{ml} \mathrm{H}_{2} \mathrm{SO}_{4}$ solution (pH 1-2) was added to a leaf of dried Securinega suffruticosa (obtained from Traditional Chinese Medicine and Natural Products, Jinan University, Guangzhou, China) in a $1,000 \mathrm{ml}$ beaker to be moistened sufficiently for $20 \mathrm{~min}$ before being transferred to a percolator and percolated at a rate of $4-5 \mathrm{ml} / \mathrm{min}$. The acidic extract was collected and passed through a cationic exchange column, which was packed with $80 \mathrm{~g}$ wet resin, at the rate of $4-5 \mathrm{ml} / \mathrm{min}$. The resin was then washed and dried at room temperature. The dried resin was alkalified with ammonia water ( $\mathrm{pH}$ 8-9). Benzin was used to elute the resin for $2.5 \mathrm{~h}$ at $60^{\circ} \mathrm{C}$. The resin petroleum extract was parboiled with agitation at $50^{\circ} \mathrm{C}$, then filtered until the crystals were separated out. Spectral techniques, including infra-red spectroscopy, ultraviolet-visible spectroscopy, mass spectrometry and nuclear magnetic resonance spectroscopy were used to identify the structure of the crystal, and X-ray crystallography, circular dichroism and Mosher chiral reagents were used to determine the absolute configuration of the product, as previously described $(22,23)$. Finally, L-securinine was extracted and isolated, as described in the previous studies (Fig. 1).

Cell culture. The human lung cancer A549 cell line and human lung fibroblast HLF-a cell line (Cell Bank of Type Culture Collection of Chinese Academy of Sciences, Shanghai, China) were cultured in RPMI-1640 supplemented with $10 \%$ heat-inactivated fetal bovine serum (FBS) (both from Thermo Fisher Scientific, Inc., Waltham, MA, USA), penicillin $(10 \mathrm{U} / \mathrm{ml})$ and streptomycin $(10 \mu \mathrm{g} / \mathrm{ml})$, in a humidified incubator (Sanyo XD-101; Sanyo Electric Co., Ltd., Osaka, Japan) with $5 \% \mathrm{CO}_{2}$ at $37^{\circ} \mathrm{C}$.

Cell cytotoxicity. The exponentially growing human lung cancer cell suspension $(5,000$ cells/100 $\mu \mathrm{l})$ was seeded into each well of 96-well plates. The cells were pre-incubated for $24 \mathrm{~h}$ in the humidified incubator at $37^{\circ} \mathrm{C}$ with $5 \% \mathrm{CO}_{2}$. Various concentrations of L-securinine from 0 to $160 \mu \mathrm{g} / \mathrm{ml}(10 \mu \mathrm{l})$ were added into each well. The cells were then incubated for 24, 36 and $48 \mathrm{~h}$ in the incubator. CCK-8 solution (10 $\mu \mathrm{l}$; cat no. KGA317; Nanjing KeyGen Biotech Co., Ltd., Nanjing, China) was added to each well and incubated for $3 \mathrm{~h}$. The absorbance of the wells at $450 \mathrm{~nm}$ was measured using a microplate reader (ELx800; BioTek Instruments, Inc., Winooski, VT, USA). The inhibition rate (IR) of cell proliferation was calculated according to the following formula: $\mathrm{IR}=[1-$ (average A450 values of the experimental group - average A450 values of the blank group)/(average A450 values of the control group-average A450 values of the blank group)] x100\%. The experimental groups and the control groups refer to the cells in the 96-well plates treated with or without L-securinine, respectively. The

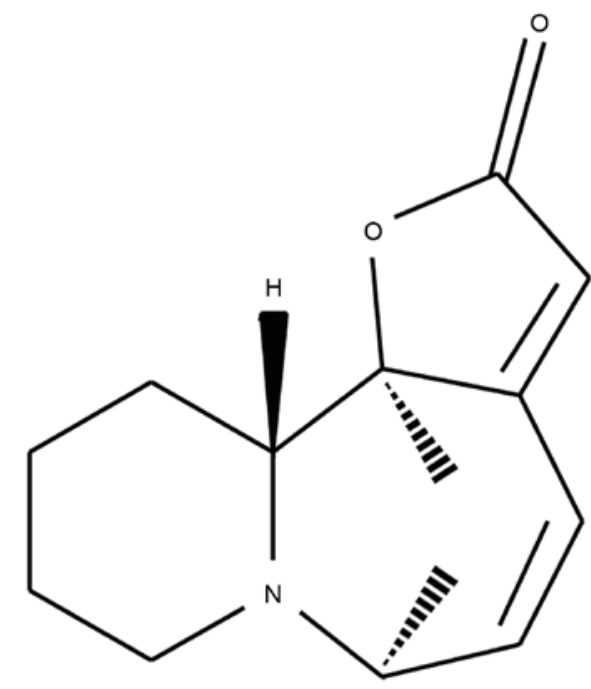

Figure 1. Structure of L-securinine. L-securinine was extracted and isolated from the leaf of dried Securinega suffruticosa. Spectral techniques, including infra-red spectroscopy, ultraviolet-visible spectroscopy, mass spectrometry and nuclear magnetic resonance were used to identified the structure of the crystal, and X-ray crystallography and circular dichroism were used to determine the absolute configuration.

blank groups refer to the lung cancer cell suspension in the wells of 96-well plates replaced by physiological saline.

$R T-q P C R$. The RT-qPCR assays were performed on HLF-a and A549 cells treated with or without L-securinine to determine the expression of the DKK genes. Total RNA was extracted from the cells using TRIzol reagent (cat no. 15596-026; Invitrogen; Thermo Fisher Scientific, Inc.). Complementary DNA (cDNA) was synthesized from the extracted RNA using a cDNA synthesis kit (cat no. PC0002; Fermentas; Thermo Fisher Scientific, Inc.), according to the manufacturer's protocol. Each PCR reaction was performed in a final volume of $20 \mu \mathrm{l}$ that contained $2 \mu \mathrm{l}$ cDNA, $10 \mu \mathrm{l}$ SYBR-Green Master Mix (cat no. QPK-201; Takara Bio, Inc., Otsu, Japan), $0.8 \mu \mathrm{l}$ of the primer mixture (forward and reverse; $10 \mu \mathrm{mol}$ ) and $7.2 \mu \mathrm{l}$ DEPC water. PCR reactions were performed using the FTC-3000 real-time fluorescence quantitative PCR system (Funglyn Biotech, Inc., Ontario, Canada). The thermocycling conditions were as follows: $95^{\circ} \mathrm{C}$ for $180 \mathrm{sec}$, followed by 40 cycles of $95^{\circ} \mathrm{C}$ for $5 \mathrm{sec}$ and $60^{\circ} \mathrm{C}$ for $30 \mathrm{sec}$. The experiment was repeated three times and all data were compared with GAPDH gene using the $2^{-\Delta \Delta C \mathrm{Cq}}$ method (24). The sequences of specific primers for GAPDH and target genes were as follows: GAPDH forward, 5'-TGTTGCCATCAATGA CCCCTT-3' and reverse, 5'-CTCCACGACGTACTCAGCG-3'; DKK1 forward, 5'-GGGGTGAAGAGTGTTAAAGGTTT-3' and reverse, 5'-CCCAAAATCCTAACTACAAAAAACA-3'; DKK2 forward, 5'-GCTGTGCTCGTCATTTCTGGA-3' and reverse, 5'-TTGGAGGAGTAGGTGGCATCTT-3'; DKK3 forward, 5'-GCGAGGTTGAGGAACTGATGG-3' reverse, 5'-CCTTCGTGTCTGTGTTGGTCTC-3'.

DNA extraction and bisulfite treatment. The A549 cells were treated with $5.0 \mu \mathrm{g} / \mathrm{ml} \mathrm{L}$-securinine and $10.0 \mu \mathrm{g} / \mathrm{ml} 5$-azacytidine (cat no. A2385; Sigma-Aldrich; Merck KGaA, Darmstadt, 
Table I. Reverse transcription-quantitative polymerase chain reaction analysis of DKK expression in A549 and HLF-a cell lines.

\begin{tabular}{lccr}
\hline Human lung cell lines & DKK1/GAPDH & DKK2/GAPDH & DKK3/GAPDH \\
\hline HLF-a & $1.003 \pm 0.02$ & $1.004 \pm 0.07$ & $1.005 \pm 0.12$ \\
A549 & $2.33 \pm 0.17$ & $15.71 \pm 0.55$ & $759.45 \pm 141.15$ \\
t-value & 13.08 & 45.64 & 9.31 \\
P-value & $<0.001$ & $<0.001$ & 0.001 \\
\hline
\end{tabular}

DKK, dickkopf-related protein.

Table II. Reverse transcription-quantitative polymerase chain reaction analysis of DKK expression in A549 cell lines.

\begin{tabular}{lccc}
\hline Concentration of L-securinine $(\mu \mathrm{g} / \mathrm{ml})$ & DKK1/GAPDH & DKK2/GAPDH & DKK3/GAPDH \\
\hline 0 & $2.33 \pm 0.17$ & $15.71 \pm 0.55$ & $759.45 \pm 141.15$ \\
2.5 & $1.53 \pm 0.08^{\mathrm{a}}$ & $17.28 \pm 5.07$ & $838.16 \pm 31.67$ \\
5.0 & $1.26 \pm 0.02^{\mathrm{b}}$ & $13.26 \pm 2.06$ & $784.56 \pm 227.69$ \\
10.0 & $1.14 \pm 0.05^{\mathrm{c}}$ & $14.53 \pm 2.74$ & $845.29 \pm 151.86$ \\
F value & 85.33 & 0.94 & 0.217 \\
P-value & $<0.001$ & 0.467 & 0.882 \\
\hline
\end{tabular}

DKK, dickkopf-related protein. ${ }^{\mathrm{a}} \mathrm{P}<0.05$ vs. $0 \mu \mathrm{g} / \mathrm{ml}$; ${ }^{\text {P }}<0.05$ vs. $2.5 \mu \mathrm{g} / \mathrm{ml}$; ${ }^{~} \mathrm{P}<0.05$ vs. $5 \mu \mathrm{g} / \mathrm{ml}$ (Student-Newman-Keuls test).

Germany). Genomic DNA was extracted from HLF-a and A549 cells using a DNA extraction kit (Aidalb Biotechnologies Co., Ltd., Beijing, China) according to the manufacturer's protocol. Then the genomic DNA was treated with sodium bisulfite using the EZ DNA Methylation ${ }^{\mathrm{TM}}$-GOLD kit (Zymo Research, Irvine, CA, USA) following the manufacturer's protocol.

BSP amplifiction. The BSP primer of DKK1 was designed using ABI Methyl Primer Express 1.0 software (Applied Biosystems; Thermo Fisher Scientific, Inc.). The primer sequence was as follows: Forward, 5'-GGGGTGAAGAGT GTTAAAGGTTT-3' and reverse, 5'-CCCAAAATCCTAACT ACAAAAAACA-3'. The PCR reaction was performed on the ABI 7500 Fast Real-Time PCR platform (Applied Biosystems; Thermo Fisher Scientific, Inc.) in a volume of $50 \mu$ l containing $5 \mu \mathrm{l}$ buffer (10X), $5 \mu \mathrm{l}$ dNTPs $(2 \mathrm{mM}), 3 \mu 1 \mathrm{MgSO}_{4}(25 \mathrm{mM})$, $1.5 \mu \mathrm{l}$ forward primer $(10 \mathrm{pmol} / \mu \mathrm{l}), 1.5 \mu \mathrm{l}$ reverse primer

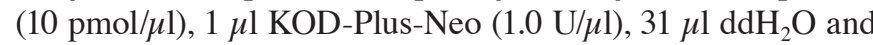
$2 \mu$ l DNA template. The thermocycling conditions were as follows: $94^{\circ} \mathrm{C}$ for $2 \mathrm{~min}, 98^{\circ} \mathrm{C}$ for $10 \mathrm{sec}$ for $25-45$ cycles, $68^{\circ} \mathrm{C}$ for $30 \mathrm{sec}$, followed by $94^{\circ} \mathrm{C}$ for $2 \mathrm{~min}, 98^{\circ} \mathrm{C}$ for $10 \mathrm{sec}, \mathrm{T}_{\mathrm{m}}{ }^{\circ} \mathrm{C}$ for $30 \mathrm{sec}$ for $25-45$ cycles, $68^{\circ} \mathrm{C}$ for $30 \mathrm{sec}$. The amplified products were sent to Sangon Biotech Co., Ltd. (Shanghai, China) for sequence analysis.

Statistical analysis. The data were processed using Microsoft Excel 2007 (Microsoft Corporation, Redmond, WA, USA) and SPSS 16.0 software (SPSS, Inc., Chicago, IL, USA) and presented as the mean \pm standard deviation. Statistically significant differences between two groups were analyzed using the Student's t-test, and pairwise comparison among the

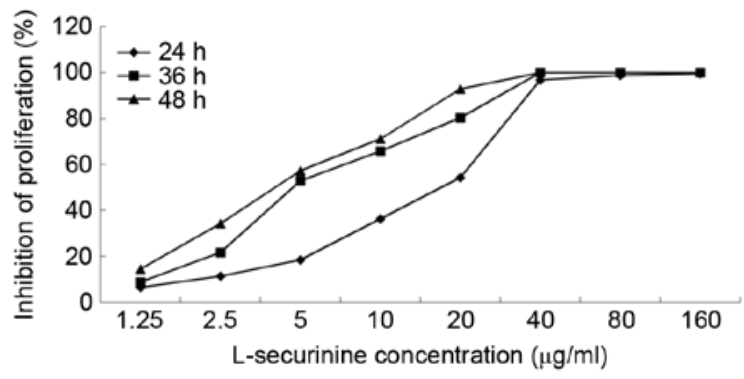

Figure 2. L-securinine inhibits the growth of A549 cells. A CCK-8 assay was used to determine the effects of L-securinine on the proliferation of A549 cells. The IR of cell proliferation was calculated according to the following formula: IR $=[1$ - (average A450 values of the experimental group-average A450 values of the blank group)/(average A450 values of the control group-average A450 values of the blank group)] x100\%. L-securinine decreased the viability of A549 cells in a dose-and time-dependent manner, with half-maximal inhibitory concentration values of 8.92, 4.73 and $3.81 \mu \mathrm{g} / \mathrm{ml}$, at 24,36 and $48 \mathrm{~h}$, respectively. IR, inhibition rate.

groups was performed using the Student-Newman-Keuls test. $\mathrm{P}<0.05$ was considered to indicate a statistically significant difference.

\section{Results}

L-securinine inhibited the growth of A549 cells. The CCK-8 assay was used to determine the effects of L-securinine on the proliferation of A549 cells. L-securinine decreased the proliferation of A549 cells in a dose- and time-dependent manner (Fig. 2), with half maximal inhibitory concentration $\left(\mathrm{IC}_{50}\right)$ values of $8.92,4.73$ and $3.81 \mu \mathrm{g} / \mathrm{ml}$ at 24,36 and $48 \mathrm{~h}$ 

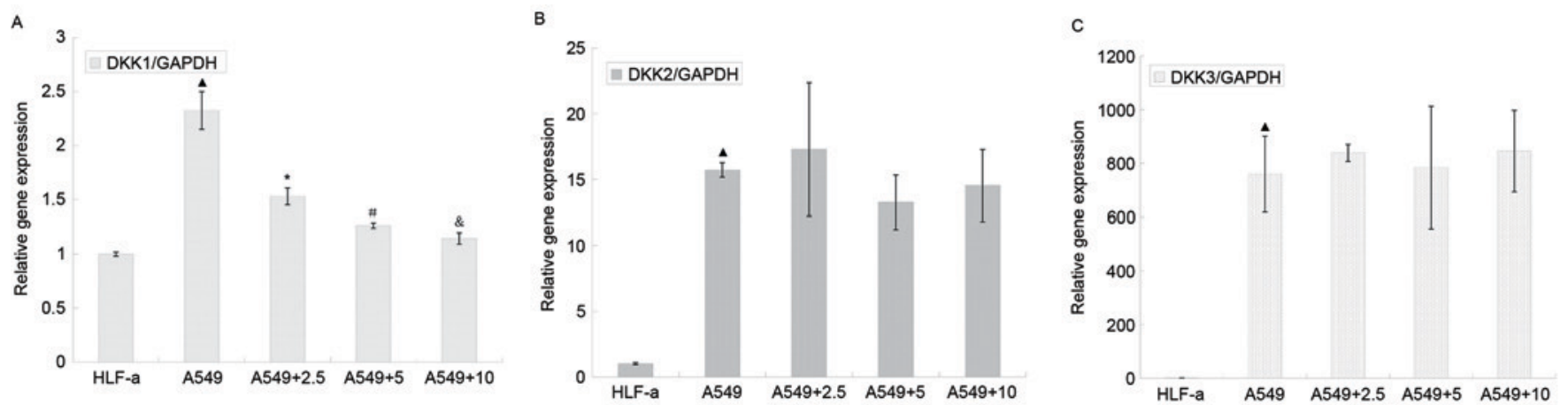

Figure 3. Expression of (A) DKK1, (B) DKK2 and (C) DKK3 in HLF-a cells and A549 cells. Reverse transcription-quantitative polymerase chain reaction assays were used to measure the expression of DKK1, 2 and 3 genes in HLF-a cells and A549 cells treated without or with 2.5, 5, 10 $\mu \mathrm{g} / \mathrm{ml} \mathrm{L-securinine}$ DKK1, DKK2 and DKK3 expression in the A549 cells were significantly increased compared with that in HLF-a cells. DKK1 gene expression, but not DKK2 or 3 expression, was significantly downregulated following treatment with $\mathrm{L}$-securinine. ${ }^{\mathbf{}} \mathrm{P}<0.05$ vs. HLF-a (t-test); ${ }^{*} \mathrm{P}<0.05$ vs. A549, ${ }^{\text {"P }} \mathrm{P}<0.05$ vs. A549 + $2.5 \mu \mathrm{g} / \mathrm{ml} \mathrm{L}$-sec and ${ }^{\&} \mathrm{P}<0.05$ vs. $5 \mu \mathrm{g} / \mathrm{ml} \mathrm{L}$-sec (Student-Newman-Keuls test). DKK, dickkopf-related protein.

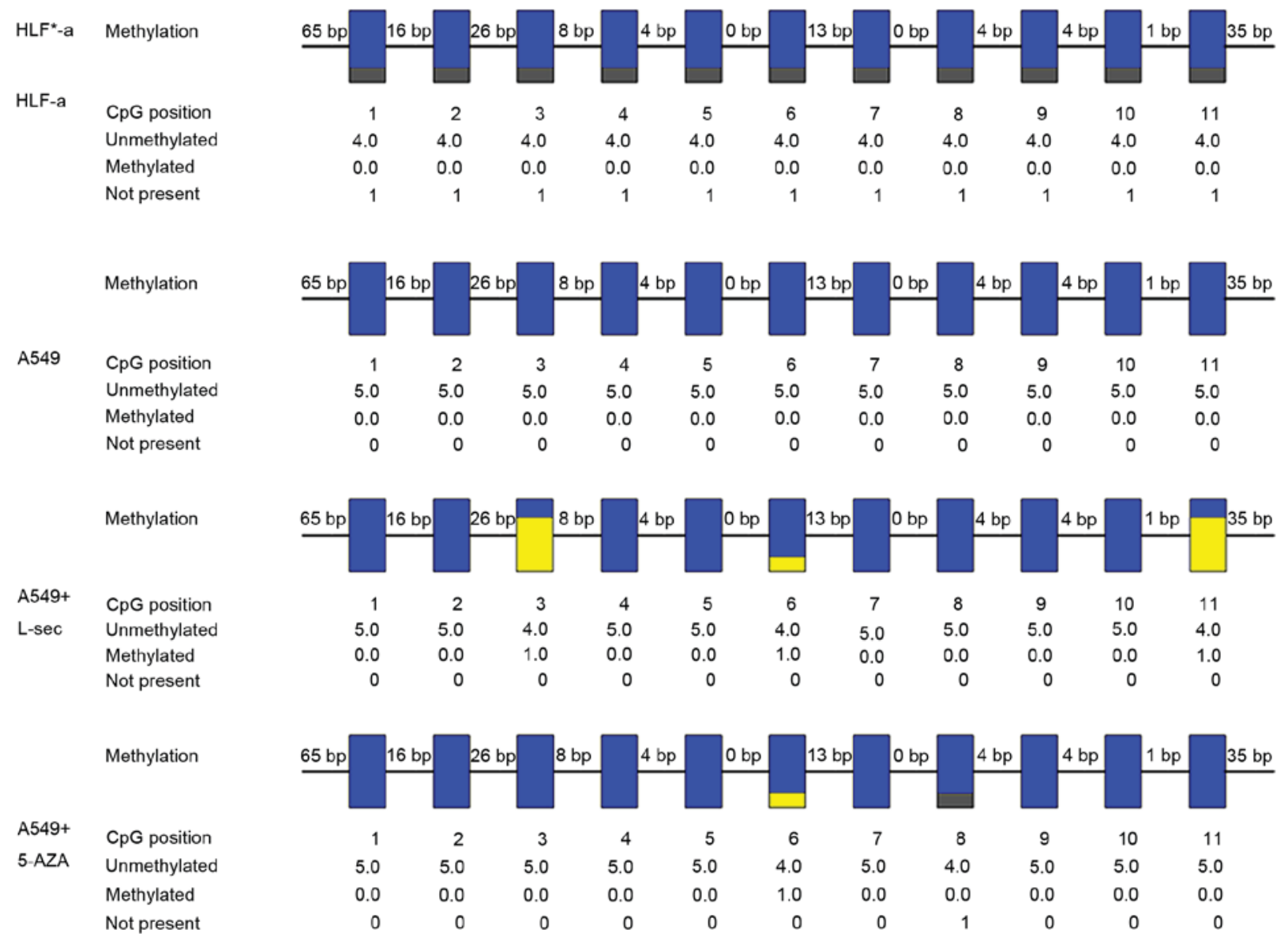

Figure 4. Methylation profile at CpG sites within the DKK1 promoter region. Methylation profile at $11 \mathrm{CpG}$ sites of the DKK1 promoter region were detected using B bisulfite sequencing polymerase chain reaction. Grey indicates where DKK1 gene variation may have occurred in HLF-a cells. Blue indicates where no methylation was detected in the promoter of the DKK1 gene from the A549 cells. Yellow indicates the third, the sixth and the eleventh CpG sites were methylated specifically in the DKK1 gene in the A549 cells treated with L-securinine. DKK, dickkopf-related protein.

post-treatment, respectively. An extract is considered cytotoxic when it possesses an $\mathrm{IC}_{50}$ value $\leq 20 \mu \mathrm{g} / \mathrm{ml}(25)$; therefore L-securinine is cytotoxic against A549 cells.

DDK expression in A549 and HLF-a cells. The A549 and HLF-a cell lines represent human lung cancer cells and lung fibroblasts, respectively. RT-qPCR assays were used to measure the expression of DKK1, 2 and 3 in HLF-a and A549 cell lines. DKK1, DKK2 and DKK3 expression was significantly increased in A549 lung cancer cells compared with HLF-a lung fibroblasts ( $\mathrm{P} \leq 0.001$; Table I and Fig. 3$)$.

DDK expression in A549 cells treated with L-securinine. A549 cells were treated without or with $\mathrm{L}$-securinine at 2.5, 5.0 and 
$10.0 \mu \mathrm{g} / \mathrm{ml}$ for $48 \mathrm{~h}$. DKK1, DKK2 and DKK3 expression were then measured using RT-qPCR. DKK1 expression was significantly decreased in a dose-dependent manner following treatment with L-securinine compared with untreated cells $(\mathrm{P}<0.05)$; however, no significant differences were observed in DKK 2 or 3 expression levels in treated compared with untreated cells (Table II and Fig. 3).

Methylation profile at $C p G$ sites within the DKK1 promoter region. The DKK1 gene was extracted from HLF-a cells, A549 cells, A549 cells treated with L-securinine and A549 cells treated with 5-azacytidine. The methylation profiles at $11 \mathrm{CpG}$ sites of the DKK1 promoter region were detected using BSP (Fig. 4). 5-azacytidine is a demethylating agent typically used in methylation research for a comparison with other sources of methylation or demethylation (26). The third, the sixth and eleventh $\mathrm{CpG}$ sites were methylated specifically in the DKK1 gene extracted from the A549 cells treated with L-securinine compared with untreated A549 cells. However, only the third and eleventh CpG sites were methylated specifically in A549 cells treated with L-securinine compared with cells treated with 5-azacytidine. Combined with the aforementioned RT-qPCR results, there may be an association between the methylation changes at CpG sites in the DKK1 promoter region and changes in the expression level of DKK1 gene following treatment with L-securinine.

\section{Discussion}

Lung cancer remains the leading cause of cancer-associated mortalities worldwide, despite improved tools for early detection. Therapeutic stratification would be expected to increase the survival rate $(27,28)$. Although certain targeted drugs, including epidermal growth factor receptor tyrosine-kinase and anaplastic lymphoma kinase/proto-oncogene tyrosine-protein kinase ROS inhibitors (29) have been used in the clinic, their cost (30) and acquired resistance (31) remain challenges for their use in the treatment of lung cancer. Therefore further studies are required to identify alternative treatment strategies. Securinine has previously been used in the clinic for the treatment of blood and nervous system diseases (32); therefore, the pharmacokinetic and pharmacodynamics properties of securinine are well understood.

Identifying alterations in the signal transduction pathways that promote lung cancer, including epigenetic modifications, may reveal biomarkers that can be used for the diagnosis and treatment of lung cancer (33). The proteins encoded by the DKK genes represent the dickkopf family of proteins, which negatively regulate the Wnt signaling pathway (12). Data from the present study demonstrated that DKK1, DKK2 and DKK3 expression is significantly increased in lung cancer cells compared with lung fibroblasts. A previous meta-analysis revealed that DKK1 is a potential biomarker for lung cancer diagnosis (34). It has previously been reported that DKK1, as a secreted protein with two cysteine rich regions, negatively regulates the Wnt signaling pathway (35).

Epigenetic changes are prevalent in all types of cancer, serve central roles in DNA replication and repair, protein structure and function, and can be regulated with chemical agents $(36,37)$. However, the anticancer drugs that can target gene methylation have not yet been applied to clinical therapy. The present study revealed that L-securinine regulates DNA methylation in the DKK1 promoter, therefore L-securinine may be a potential therapeutic agent that can target changes in gene methylation in lung cancer cells.

In the present study, the $\mathrm{IC}_{50}$ values and growth-inhibitory curves of A549 cells treated by L-securinine were analyzed. According to the $\mathrm{IC}_{50}$ values and growth-inhibitory curves, the appropriate concentration of L-securinine was selected to treat A549 cells and analyze of the expression of DKK genes following treatment. DKK1 expression was demonstrated to be significantly decreased in A549 cells treated with L-securinine compared with that in untreated cells. The methylation profile of the DKK1 promoter was explored to identify the molecular mechanisms underlying the effect of L-securinine on DKK1 expression. Compared with 5-azacytidine, L-securinine promoted the methylation of the DKK1 promoter.

\section{Acknowledgements}

The present study was supported the National Natural Science Foundation of China (grant no. 81241102). The authors would like to thank the Institute of Traditional Chinese Medicine and Natural Products, Jinan University (Guangzhou, China) for providing the sample of Securinega suffruticosa.

\section{References}

1. Wood SL, Pernemalm M, Crosbie PA and Whetton AD: Molecular histology of lung cancer: From targets to treatments. Cancer Treat Rev 41: 361-375, 2015.

2. Carcereny E, Morán T, Capdevila L, Cros S, Vilà L, de Los Llanos Gil M, Remón J and Rosell R: The epidermal growth factor receptor (EGRF) in lung cancer. Transl Respir Med 3: 1, 2015 .

3. Li LN, Chen WM and Fang QC: Studies on the extraction and isolation of securinine from securinega suffruticosa (PALL.) REHD by adsorption with active carbon. Yao Xue Xue Bao 9: 352-358, 1962 (In Chinese).

4. Saito S, Kotera K, Shigematsu N, Ide A, Sugimoto N, Horii Z, Hanaoka M, Yamawaki Y and Tamura Y: Structure of securinine. Tetrahedron 19: 2085-2099, 1963.

5. Gupta K, Chakrabarti A, Rana S, Ramdeo R, Roth BL, Agarwal ML, Tse W, Agarwal MK and Wald DN: Securinine, a myeloid differentiation agent with therapeutic potential for AML. PLoS One 6: e21203, 2011.

6. Treatment of chronic aplastic anemia with securinine-analysis of 123 cases. Zhonghua Nei Ke Za Zhi 22: 764-766, 1983 (In Chinese).

7. Neganova ME, Klochkov SG, Afanasieva SV, Serkova TP, Chudinova ES, Bachurin SO, Reddy VP, Aliev G and Shevtsova EF: Neuroprotective effects of the securinine-analogues: Identification of Allomargaritarine as a lead compound. CNS Neurol Disord Drug Targets 15: 102-107, 2016.

8. Beutler JA, Karbon EW, Brubaker AN, Malik R, Curtis DR and Enna SJ: Securinine alkaloids: A new class of GABA receptor antagonist. Brain Res 330: 135-140, 1985.

9. Copperman R, Copperman G and Der Marderosian A: From Asia securinine-a central nervous stimulant is used in treatment of amytrophic lateral sclerosis. Pa Med 76: 36-41, 1973.

10. Li M, Han S, Zhang G, Wang Y and Ji Z: Antiproliferative activity and apoptosis-inducing mechanism of L-securinine on human breast cancer MCF-7 cells. Pharmazie 69: 217-223, 2014.

11. Han S, Zhang G, Li M, Chen D, Wang Y, Ye W and Ji Z: L-securinine induces apoptosis in the human promyelocytic leukemia cell line HL-60 and influences the expression of genes involved in the PI3K/AKT/mTOR signaling pathway. Oncol Rep 31: 2245-2251, 2014. 
12. Choi HJ, Park H, Lee HW and Kwon YG: The Wnt pathway and the roles for its antagonists, DKKS, in angiogenesis. IUBMB Life 64: 724-731, 2012.

13. Abdel-Magid AF: Wnt/ $\beta$-catenin signaling pathway inhibitors: A promising cancer therapy. ACS Med Chem Lett 5: 956-957, 2014

14. Xue G, Romano E, Massi D and Mandalà $M$ : Wnt/ $\beta$-catenin signaling in melanoma: Preclinical rationale and novel therapeutic insights. Cancer Treat Rev 49: 1-12, 2016.

15. Chandra V and Hong KM: Effects of deranged metabolism on epigenetic changes in cancer. Arch Pharm Res 38: 321-337, 2015.

16. Walter K, Holcomb T, Januario T, Yauch RL, Du P, Bourgon R, Seshagiri S, Amler LC, Hampton GM and S Shames D: Discovery and development of DNA methylation-based biomarkers for lung cancer. Epigenomics 6: 59-72, 2014.

17. Ko M, An J, Pastor WA, Koralov SB, Rajewsky K and Rao A: TET proteins and 5-methylcytosine oxidation in hematological cancers. Immunol Rev 263: 6-21, 2015.

18. Carless MA: Investigation of genomic methylation status using methylation-specific and bisulfite sequencing polymerase chain reaction. Methods Mol Biol 1288: 193-212, 2015.

19. Jiang M, Zhang Y, Fei J, Chang X, Fan W, Qian X, Zhang T and Lu D: Rapid quantification of DNA methylation by measuring relative peak heights in direct bisulfite-PCR sequencing traces. Lab Invest 90: 282-290, 2010.

20. Hughes S and Jones JL: The use of multiple displacement amplified DNA as a control for methylation specific PCR pyrosequencing, bisulfite sequencing and methylation-sensitive restriction enzyme PCR. BMC Mol Biol 8: 91, 2007.

21. Reed K, Poulin ML, Yan L and Parissenti AM: Comparison of bisulfite sequencing PCR with pyrosequencing for measuring differences in DNA methylation. Anal Biochem 397: 96-106, 2010.

22. Chirkin E, Atkatlian W, Do Q, Gaslonde T, Dufat TH, Michel S, Lemoine P, Genta-Jouve G and Porée FH: Chiroptical study and absolute configuration of securinine oxidation products. Nat Prod Res 29: 1235-1242, 2015.

23. Wang Xiao, Ming Zheng and Hong Yan: The extraction technology of securinine. Agricultural Food Products Science and Technology 5: 6-1112, 2011.

24. Livak KJ and Schmittgen TD: Analysis of relative gene expression data using real-time quantitative PCR and the 2(-Delta Delta C(T)) method. Methods 25: 402-408, 2001

25. Navanesan S, Abdul Wahab N, Manickam S and Sim KS: Leptospermum flavescens constituent-LF1 causes cell death through the induction of cell cycle arrest and apoptosis in human lung carcinoma cells. PLoS One 10: e0135995, 2015.
26. Sood S and Srinivasan R: Alterations in gene promoter methylation and transcript expression induced by cisplatin in comparison to 5-Azacytidine in HeLa and $\mathrm{SiHa}$ cervical cancer cell lines. Mol Cell Biochem 404: 181-191, 2015.

27. Nardi-Agmon I and Peled N: Exhaled breath analysis for the early detection of lung cancer: Recent developments and future prospects. Lung Cancer (Auckl) 8: 31-38, 2017.

28. Chen Z, Mei J, Liu L, Wang G, Li Z, Hou J, Zhang Q, You Z and Zhang L: PD-L1 expression is associated with advanced non-small cell lung cancer. Oncol Lett 12: 921-927, 2016.

29. Ge L and Shi R: Progress of EGFR-TKI and ALK/ROS1 inhibitors in advanced non-small cell lung cancer. Int J Clin Exp Med 8: 10330-10339, 2015.

30. Atherly AJ and Camidge DR: The cost-effectiveness of screening lung cancer patients for targeted drug sensitivity markers. Br J Cancer 106: 1100-1106, 2012.

31. Lantermann AB, Chen D, McCutcheon K, Hoffman G, Frias E, Ruddy D, Rakiec D, Korn J, McAllister G, Stegmeier F, et al: Inhibition of casein kinase 1 alpha prevents acquired drug resistance to erlotinib in EGFR-mutant non-small celllung cancer. Cancer Res 75: 4937-4948, 2015.

32. Yang X, Han SW, Liu H, Zhu L, Chen YX and Ji ZN: Secreted frizzled-related protein 1 (SFRP1) gene methylation changes in the human lung adenocarcinoma cells treated with L-securinine. J Asian Nat Prod Res: 1-19, 2017.

33. Gills JJ, Granville CA and Dennis PA: Targeting aberrant signal transduction pathways in lung cancer. Cancer Biol Ther 3: 147-155, 2004.

34. Jiang XT, Ma YY, Guo K, Xia YJ, Wang HJ, Li L, He XJ, Huang DS and Tao HQ: Assessing the diagnostic value of serum Dickkopf-related protein 1 levels in cancer detection: A case-control study and meta-analysis. Asian Pac J Cancer Prev 15: 9077-9083, 2014

35. Tian J, Xu XJ, Shen L, Yang YP, Zhu R, Shuai B, Zhu XW, Li CG, $\mathrm{MaC}$ and Lv L: Association of serum Dkk-1 levels with $\beta$-catenin in patients with postmenopausal osteoporosis. J Huazhong Univ Sci Technolog Med Sci 35: 212-218, 2015.

36. Sonohara F, Inokawa $\mathrm{Y}$, Hayashi M, Kodera $\mathrm{Y}$ and Nomoto $\mathrm{S}$ : Epigenetic modulation associated with carcinogenesis and prognosis of human gastric cancer. Oncol Lett 13: 3363-3368, 2017.

37. Shinjo K and Kondo Y: Targeting cancer epigenetics: Linking basic biology to clinical medicine. Adv Drug Deliv Rev 95: 56-64, 2015. 